\title{
IDENTIFICATION PART OF SPEECH OF ENGLISH WORD BEFORE
}

\author{
Tiara Arista Fitriani \\ English Department of UNIKOM \\ aristafitrianitiara@gmail.com
}

\begin{abstract}
The study analyzes the fact that before lead to different categories based on their distribution in English sentence; the study focuses on examining the occurrence of before as a particular word category in sentence. Thus, this study aims to discuss the categories of before and to identify what constituent that determines the categories of before and According to those aim, this study takes a title, 'Identification Part of Speech of English Words Before.' For this study, the data were collected from COCA (Corpus of Contemporary American English) as the main source of research data. The data were identified by observing the sentence that contained word before, and then were classified into their specific categories. Lastly, the data were analyzed using Radford's theory (2004).

The results of the study show that there are three categories of words before; those are, prepositions, adverbial, and conjunctions. After analyzing comprehensively, the results are: (1) the word before as adverb is following the other adverb or verb (2) the word before as the conjunction are followed by clause that is constituted by subject and verb, (3) the word before as the preposition is followed by the noun phrase. However in this article the word before as conjunction can be preposition when the subject and the verb of the clause are reduced.
\end{abstract}

Keywords: Adverb, Before, Conjunction, Preposition

\begin{abstract}
Abstrak
Studi ini menganalisis fakta bahwa kata before memiliki kategori yang berbeda berdasarkan distribusinya dalam kalimat bahasa Inggris, penelitian berfokus pada kata before yang memiliki kategori kata tertentu dalam kalimat bahasa Inggris . Dengan demikian, penelitian ini bertujuan untuk membahas kategori before dan untuk mengidentifikasi konstituen apa yang menentukan kategori kata before pada kalimat, penelitian ini mengambil judul, 'Identifikasi Kelas Kata bahasa Inggris Before.'

Untuk penelitian ini, data yang dikumpulkan dari COCA (Corpus of Contemporary American English) sebagai sumber utama data penelitian. Data diidentifikasi
\end{abstract}


dengan mengamati kalimat yang berisi kata before, kemudian diklasifikasikan ke dalam kategori tertentu mereka. Terakhir, data dianalisis dengan menggunakan teori Radford (2004).

Hasil penelitian menunjukkan bahwa ada tiga kategori kata sebelum dan sesudah; mereka adalah, preposisi, adverbial, dan konjungsi. Setelah menganalisis secara komprehensif, disimpulkan bahwa: (1) kata before sebagai kata adverbial mengikuti adverbia lain atau kata kerja kata, (2)kata before sebagai konjungsi diikuti oleh klausa yang dibentuk oleh subjek dan kata kerja. (3) before sebagai preposisi diikuti oleh prasa nomina atau determiner phrase. Namun, pada artikle ini kata before dapat berubah menjadi preposisi ketika subjek serta kerja pada klausa tersebut direduksi.

Kata kunci: Adverbia, Before, Konjungsi, Preposisi

\section{Introduction}

Every word has its own part of speech and own contribution when it collocated with other part of speech. Part of speech is also known as word classes. Kroeger (2005: 33) assumes that There are eight word classes in English words: (1) Noun is the part of speech that is usually defined as the name of the place, person, and things (2) Adjective is the part of speech that is usually defined as characteristic of something or somebody (3) Verb is the part of speech that is usually defined as the event or action that doing by somebody or something (4) Adverb is the part of speech that is usually defined as the word that modifies verb, adjective or the other adverb (5) Conjunction is the part of speech that is usually defined as the word that joining word with other word, phrase with other phrase, clause and the other clause (6) Preposition is the part of speech that is usually defined as the word that connect noun with the other part of sentence (7) Determiner is the part of speech that is usually defined as the word that used to limit of the word noun (8) interjection is the part of speech that is usually defined as the word to express feeling. There is the part of speech usually used that is pronoun. Kroeger (2005: 45) also states that pronoun is the sub part of speech of noun that is usually defined as the word that substitute noun

Each word usually has one part of speech However, the word before have three parts of speech that are adverb, conjunction, and preposition. Referring on the phenomenon of issue discussed, before may act in different categories regarded to their distribution Randolph based on Quirk et al (1985). In order to illustrate the categories of the words before the sentence structure may be analyzed by using tree diagram by Radford and to show what constituent that make differences of word before in each categories to make easier the reader to identify the part of speech of the word before in the future. 


\section{Data Source}

For this article, the data were collected from COCA (Corpus of Contemporary American English) as the main source of research data. Djajasudarma and Citraresmana (2016: 106) assume here were two principles to choose linguistic corpus as a data: (1) The chosen data that were used as the research data, depend on several factors, that are, the confidence doing the research, researcher interest, and referring to previous hypothesis; and (2) events repetition was significant. That means the frequency of the data appearance is good to show the language use._A statement about validity of corpus is also stated by Xiao (2009), "corpus data can indeed contribute to linguistic theory, because corpora can provide attested, contextualized and quantitative language data." Based on the assumptions, this research uses a valid data.

COCA is chosen because it contains lots of words from various media such magazine, novel, and journal, showing that the words before usually used in every types of writing.

\section{Method}

In collecting the data, several steps are conducted. First, search the word that contains the word before. Second, after finding the data, the data are classified using the writer knowledge. After that, the data are analyzed based on Syntax scope that Radford tree diagram theory (2004).

This article is a qualitative descriptive article. Uwe Flick stated (2009: 45) "qualitative article is centrally concerned with the production and analysis of texts, such as transcripts of interviews or field notes and other analytic materials." Based on the quotation, this article is classified as a qualitative article because this article is focused on analysis text or analytic material by look at structure, and the word that build the text. This article also uses descriptive analytic method in order to analyze the data. The data that already collected are described based on the type of sentence. After that the data are analyzed using the theory and describe that. As Sugiyono Stated (2013:3) "penelitian yang dimaksudkan untuk menyelidiki keadaan, kondisi, ataiu hal-hal lain yang sudah disebutkan, yang hasilnya dipaparkan dalam bentuk laporan penelitian" Thus, the data is analyzed and described in the article report by applying theory mentioned earlier.

\section{Theoretical Review}

This research uses tree diagram theory as the grand theory to analyze the sentence structure. The theory is quoted from Andrew Radford in his book titled "Minimalist syntax". Radford (2004:50) said that we show how the resulting structure can be represented in terms of a tree diagram, and we look at ways of 
testing the structure of phrases and sentences. Based on the quotation the data will be analyzed using tree diagram to determine the subject and the predicate of sentence. The sentence structure is built by the sentence constituents that are phrase and clause. Based on Radford theory there are:

\section{a. Tense Phrase (TP)}

Radford (2004: 54) assumes this phrase is headed by a tense or to-infinitive. Radford assumes when subject is merged with the auxiliary tense with verb phrase, it is called maximal projection. Based on the assumption, this phrase is used to illustrate the complete sentence with the auxiliary verb in the sentence or to illustrate to infinitive phrase. For example, I am eating the example shows that the word $a m$ is the tense as the head of the phrase the word $l$ is the modifier. TP is usually used in the top of tree diagram because Tense phrase symbolizes the sentence or maximal projection. However the second TP symbolizes the infinite phrase for example, to help.

\section{b. Noun Phrase (NP)}

Radford (2004: 59) states that noun phrase is headed by a Noun. This phrase is also used as a subject or object because this phrase is headed by the word noun is the name of something or places. For instance, good boy phrase shows the noun phrase with the word boy as the head and good as the modifier that modifies the head.

\section{c. Determiner Phrase (DP)}

Determiner phrases are headed by a determiner. Radford (2004: 70) assumes that function words also project phrases; by combining a determiner with a noun expression we form a determiner phrase. Thus, there is new phrase that is called determiner phrase. This phrase is usually shown by the determiner in the first phrase and this phrase has similar function with noun phrase because after the determiner there must be a noun or noun phrase. For example, The chair shows the determiner phrase with the word the as the head and the word chair as the modifier. The determiner the, as a head, modifies the specific modifier, chair

\section{d. Verb Phrase (VP)}

Based on Radford (2004: 59), verb phrase is headed by a verb. This phrase acts as the main sentence because this phrase shows the action or event of the subject, noun. For example, give the money shows the verb phrase with the word give as the head and the phrase the money as the modifier. The word give is the head that controls the action of the doer, someone. . On the other hand, the 
phrase the money plays as a modifier that modifies the head, describing that something affected by the head.

\section{e. Prepositional Phrase (PP)}

Adopt from Radford (2004: 59), prepositional phrase is headed by preposition. This phrase can be pointed out by looking at the phrase or the word after preposition; noun, pronoun, noun phrase, or determiner phrase, for example, in the room phrase shows the preposition in as the head and the determiner phrase the room as the modifier. The preposition points out the position of something.

\section{f. Adjective Phrase (AP)}

Adjective phrase is headed by Adjective based on Radford (2004: 59). This phrase is the phrase that usually comes along with noun or determiner phrase as a modifier of it. In the example the adjective phrase (AP) very good consists of adjective good and adverb very. The phrase shows the adjective phrase with the adjective good as a head controls the adverb very as the modifier. The adjective head good is a characteristic. The word very as the modifier explains about the scale of the characteristic, good.

\section{g. Adverbial Phrase (ADVP)}

Radford (2004: 59) states that adverbial phrase is headed by adverb. This phrase is the phrase that is usually used to modify a verb, adjective or the other adverb. For example, very sadly shows the adverbial phrase that consists of two adverbs with head very and the modifier sadly.

\section{h. Complementiser Phrase (CP)}

Take on Radford (2004: 107) that complementiser phrase, in traditional grammar, is usually called after the term clause. This phrase is headed by a conjunction. To point out this phrase, for example, because the room is dirty shows conjunction because preceding tense phrase (TP), the room is dirty.

\section{Findings and Discussion}

\section{DATA 1}

It was something we had never done before. (COCA, 2015: ACAD) 


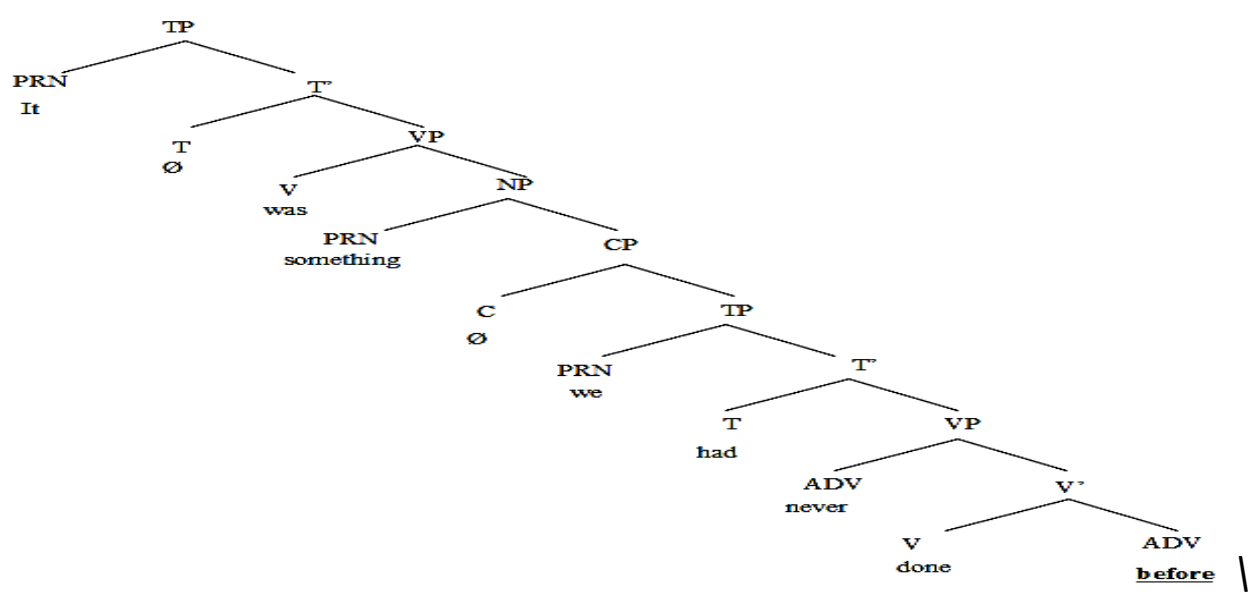

The tree diagram above shows the constituent data 1 is:

Pronoun $(\mathrm{PRN})=$ it

Verb $(\mathrm{VP})=$ was

Pronoun $(\mathrm{PRN})=$ something
Coordination (C) $=\varnothing$

Pronoun $(\mathrm{PRN})=$ we

Tense Phrase $(T P)=$ had never done before

The word before in data 1 is an adverb that modified the VP had never done. The definition of the part of speech adverb is modified verb, adjective or the other adverb. In this case, the word before as the modifier of the verb had never done. Thus, the part of speech of the word before in data 1 is adverb because the word before has function as the modifier of the part of speech verb.

\section{DATA 2}

Institutional Review Board approval was obtained before data were collected. (COCA, 2015: ACAD)

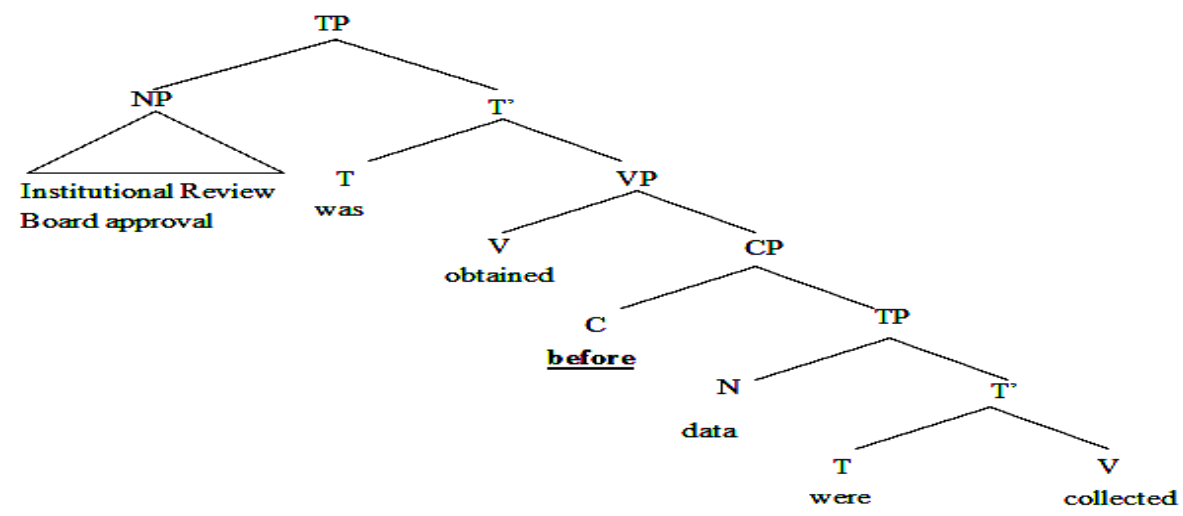


Tree diagram above show the constituents of data 2:

Noun Phrase (NP) = Institutional Review Board approval

Verb Phrase (VP) $=$ was obtained

Complementiser $(\mathrm{C})=\underline{\text { before }}$

Noun Phrase (NP) = data

Verb Phrase $(\mathrm{VP})=$ were collected

The constituent after the word before in in the tree diagram data 2 is complementiser phrase, that is built by noun phrase and verb phrase and before as a conjunction. The definition of the part of speech conjunction is joining the first clause with the other clause. In this case the first clause is "Institutional Review Board approval was obtained" and the second clause is "data were collected" that is joined by the word before between them. Thus, the part of speech of the word before in data 2 is conjunction.

\section{DATA 3}

This realization allows them to add missing components of the story before including the narration. (COCA, 2015: ACAD)

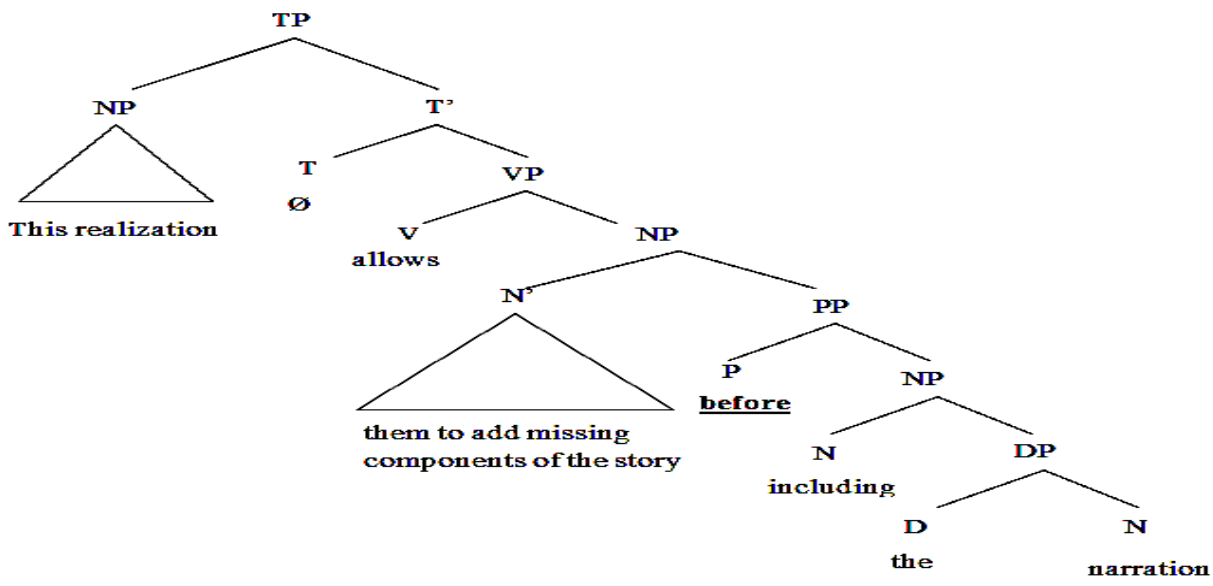

Tree diagram above show the constituents of data 3:

Noun Phrase (NP) $=$ This realization

Verb Phrase (VP) = allows

Noun Phrase (NP) = them to add missing components of the story

Prepositional phrase $(\mathrm{PP})=\underline{\text { before }}$ including the narration . 
The constituent after the word before in the tree diagram data 3 is gerund, the verb changes into noun. In this data 3 the word before can be said as a preposition. The definition of the part of speech of preposition is the part of speech that connect noun with the other part of sentence. In this case, the word before is connecting the noun phrase them to add missing components of the story with gerund including. Thus, the part of speech of the word before in data 3 is preposition. On the other hand, the word before in the data 3 is not only has function as preposition but also as conjunction. the analysis can be seen in the tree diagram below how the words before in the data 3 became conjunction:

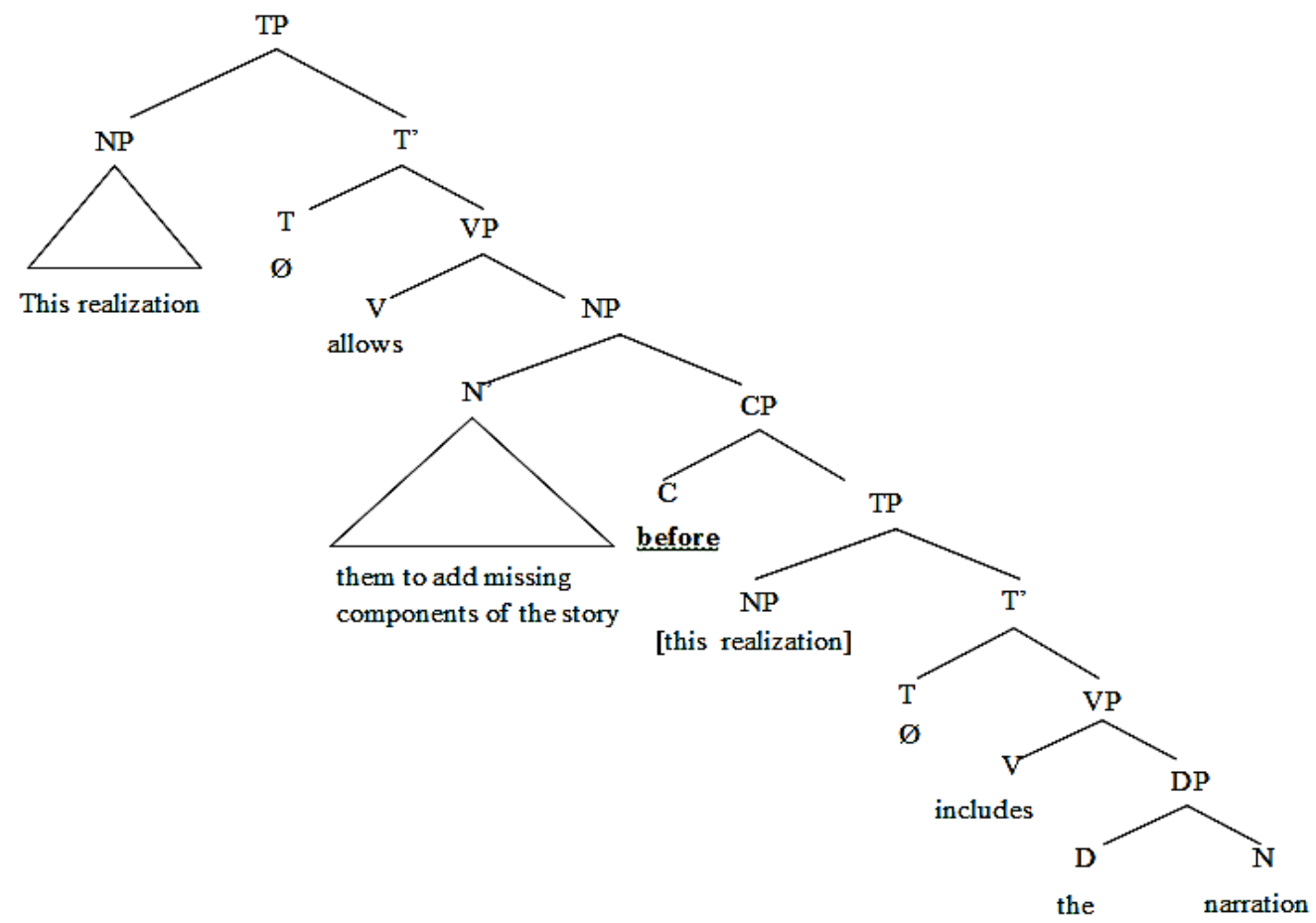

Tree diagram above show the constituents of data 3:

Noun Phrase (NP) $=$ This realization

Verb Phrase (VP) = allows

Noun Phrase (NP) = them to add missing components of the story

Complementiser $(\mathrm{C})=\underline{\text { before }}$

[Noun Phrase (NP) = this realization]

Verb Phrase (VP) = includes

Determiner phrase $(D P)=$ the narration

The tree diagram above shows the reduce clause from clause "before this realization includes the narration". The clause reduced thus, the verb of the clause 
is change into noun that can be said as gerund. Therefore in data 3 the word before can be said as conjunction and preposition.

\section{Conclusion}

In the finding and discussion, there are three data have analyzed. The first data contain the word before that have part of speech as an adverb because the word before modified the verb in the data 3 . The second data contain the word before that have part of speech as a conjunction because after the word before there is clause. The third data contain the word before as a conjunction can be preposition when the clause is reduced.

\section{References}

Corpus of Contemporary American English (COCA). Available at: http://corpus.byu.edu

Djajasudarma, Fatimah and Elvi Citraresmana. 2016. Metodologi \& Strategi Penelitian Linguistik. Bandung: Universitas Padjadjaran

Flick, Uwe. 2009. An Introduction to Qualitative Article. London: SAGE

Kroeger, Paul. R. 2005. Analyzing Grammar: An Introduction. Cambridge: Cambridge University Press

Miller, Jim. 2002. An Introduction to English Syntax. Edinburgh: Edinburgh University Press

Quirk, Randolph, Geoffrey Leech and Jan Svartvik. 1985. A Comprehensive Grammar of the English Language. London : Longman.

Radford, Andrew. 2004. Minimalist Syntax. Cambridge: Cambridge University Press

Xiao. Richard. 2009. "Theory-driven corpus research: Using corpora to inform aspect theory". Corpus Linguistic an International Hand Book. Germany: Mouton de Gruyter

Sugiyono. 2013. Metode Penelitian Kuantitatif Kualitatif dan R\&D. Bandung: Alfabeta. 
